of the Royal Society (twice), of the Royal Astronomical Society (twice), and of the Institute of Civil Engineers. Most scientific societies are proud to have his name on their list of members; he is one of the eight Associés Étrangers de l'Académie des Sciences à Paris.

\section{A. WINNECKE}

\section{FOREIGN ORDERS}

TN several articles and letters in vol. viii. of NATURE the question of the conferment of foreign orders on British subjects, so far as it concerns men of science, was pretty thoroughly discussed, as well as the proposal made in Parliament, in 1873 , to establish an order of intellectual merit. The subject has again come up in connection with the distribution of awards at the close of the Paris Exhibition, and there has been much disappointment and even bitterness of feeling expressed at the refusal of our Government to allow British subjects to accept the coveted Cross of the Legion of Honour. It is well known that many of our men of science, as well as others, possess foreign orders in abundance, and that our Government takes no notice unless consulted, when, on the ground of some antiquated regulations, it thinks it its duty to refuse permission to accept such orders. If not illegal, it is at any rate weak and childish on the part of Government to take such a course, worthy of the days of "good" Queen Bess, who wished her dogs to wear no collars but her own. In the case of the Exhibition awards it has been shown that this decision on the part of our Government falls with peculiar hardship on British exhibitors. It will very naturally be inferred by the general public that as a body they occupy an inferior position to foreign exhibitors, who are allowed to accept the great French honour, which is conspicuous by its absence from the awards in the British department. It is especially hard, we think, upon those who have served on the British jury. From some parsimonious caprice on the part of Government no allowance was made to those who served as jurors at the Paris Exhibition, and the eminent men of science who gave up their time and knowledge for the benefit of the country and the world not only go entirely unrewarded, but must have been seriously out of pocket. One case we know of and we believe it is not the only one-where a well-known chemist, besides incurring serious expense, worked so hard as to materially affect his health, and all not even for bare thanks.

So far as we ourselves are concerned, we are not anxious to see men of science eager to obtain, or easy to be satisfied, with such honours as those which, if they are simple enough to ask, they are told they must not accept. Our own Government is niggardly enough in its recognition of the services done by the scientific worker to his country; and how can it be otherwise with a Cabinet that has scarcely a member, we believe, who knows the difference between a telescope and a telephone. Fortunately for his self-respect, the purely scientific worker, however eminent he may be as such, is rarely, if ever, embarrassed by the offer of honours from our own Government. These are reserved for the militant and civil services, where, as a rule, they are least requisite, seeing that those who obtain them are generally pretty well paid for their zeal. As for what is called the "honour" of knightbood, it has now become so common, so easily obtainable, that the mere offer of it must make one suspect that after all he must be regarded by its dispensers as a very tenth-rate man. We know of a humble grocer in a small country town in the north in which a statue erected to the late Prince Consort was unveiled by the Queen, when the decent man happened to be provost ; of course he was clubbed "Sir," and his life was ever after rendered miserable by the waggish little urchins of the town, who would gravely pass their cans across the counter for "A bawbee worth o' treacle, Sir Dawvid." And C.B. is rapidly becoming little better, so that virtually in this country there is no imperial honour attainable by the purely scientific worker, however eminent, which his self-respect would permit him to accept entirely without question.

As to the creation of an orcler of merit for men of bigh eminence in science, literature, or art, we have already expressed our opinion. In the present state of things it is better to let the existing chaos alone. Who is there among those who would now have the dispensation of such an honour who is capable of selecting those really most. worthy of it? Had we a Minister of Science, with a council of scientific specialists to guide him, then there would be somechance that such an honour would reach those who really deserved it; but at present it is hopeless. Indeed the devotee of scientific research would much prefer that Government, if it desires to do science honour, would do so by giving her substantial aid to pursue her work, than that it should load her servants with all the honours at her Majesty's disposal.

Still with the parsimony both of money and "honours" at home, it is peculiarly hard that scientific men can accept the distinctions which foreign governments are ready enough to award only as if they were contraband goods. Literature and art are abundantly rewarded in both ways, but, like virtue, science, on which the substantial welfare of the world depends, is its own reward; but this, unfortunately, is not marketable. We trust that the present outcry will lead to a modification of the unreasonable regulation as to foreign orders.

\section{THE "ENCYCLOPEDIA BRITANNICA"}

The Encyclopadia Britunnica. Ninth Edition. Vols. vii. and viii. (Deacon to Fakir). (Edinburgh: A. and C. Black, I877-78.)

$\mathrm{N}$ the article ENCYCLOPADIA, which finds a place in 1 the second of the volumes now before us Mr. Lyons defines an encyclopædia as a book treating of all the various kinds of knowledge. The definition applies well enough to the older encyclopædias, composed when it. was still thought practicable to set forth in a single woris all that was worth knowing in science and art. To define the province of a modern encyclopædia is a more difficult task, which will probably be avoided by every one who is not compelled either to plan and edit a work of the kind, or to review an editor's plan. Smaller cyclopædias, on the type of the "Conversations Lexicon," naturally limit 